\title{
A QUALITATIVE STUDY ON MANAGING THE TRANSITION PRACTICES OF SENDING AND RECEIVING TEACHERS IN MAURITIUS
}

\author{
Saraswatee Rajiah \\ PhD scholar to University of KwaZulu Natal, lecturer of Psychology, Early Childhood \\ Education Unit, School of Education, Mauritius Institute of Education, Mauritius

\section{Jayaluxmi Naidoo} \\ Professor, College of Humanities, School of Education, \\ University of KwaZulu Natal, South Africa \\ Rada Tirvassen \\ Professor, Head Ancient and Modern Languages and Cultures Department, \\ Faculty of Humanities, University of Pretoria, South Africa

\section{Dr. Ruchi Tyagi} \\ Sr. Associate Professor, School of Business, \\ University of Petroleum and Energy Studies, Dehradun, India
}

\begin{abstract}
The Education Human Resources Strategic Plan 2008 - 2020 set 'Quality Education for All' as vision of the Mauritian Education Sector to support Sustainable Development Goals. The reliance on education, trade-led development, total factor productivity, increased export and human development measures allowed economic diversification in Mauritius. The successful economic diversification allowed Mauritius to move from sugar to textiles to a broader service economy with major responsibility on its Early Education. In 2017, the primary school population consisted of 92989 (50.5\% boys and $49.5 \%$ girls). There were 1500 pre-primary schools and 279 primary schools in 2001, and 883 pre-primary schools and 318 primary schools in 2017 in the island of Mauritius. The lower birth rate has reduced the number of enrolment but the number of primary schools has increased, leading more pressure on managing the transition practices for both sending and receiving teachers.
\end{abstract}

Key words: National Curriculum Framework (NCF), Transition Practices, Sending Teacher, Receiving Teacher, Transition Diary, Sustainable Development Goals (SDGs). 
Cite this Article: Saraswatee Rajiah, Jayaluxmi Naidoo, Rada Tirvassen and Ruchi Tyagi, A Qualitative Study on Managing the Transition Practices of Sending and Receiving Teachers in Mauritius, International Journal of Management (IJM), 12(3), 2021, pp. 812-822.

$\mathrm{http}: / /$ iaeme.com/Home/issue/IJM?Volume $=12 \&$ Issue $=3$

\section{BACKGROUND AND INTRODUCTION}

James Meade, a Nobel Prize recipient in economics predicted dismal future of Mauritius on three counts. First, due to its vulnerabilities to weather; second, price shocks; and third, lack of job opportunities outside the sugar sector (Meade, 2013). Mauritius GDP per capita increased more than ten-fold between 1970 and 2010, from less than $\$ 500$ to more than $\$ 6,000$ due to economic diversification (Zafar, 2011). Imports and exports have boomed together they contribute more than 100 percent of GDP during the late 1990s and 2000s (Subramanian and Roy, 2001). The education system in Mauritius is still very much 'foreign' as the system is based on foreign languages such as English and French, i.e., the curriculum and syllabus have not been subject to Mauritianisation (Hollup, 2004). The Government of Mauritius revitalised the Zones d'Education Prioritaires (ZEP) to support pupils attending low performing primary schools, and develop a national strategy for tertiary education to enhance competitiveness in the global economy (WBR, 2006). The student transition rate to secondary school is $72 \%$ (MNEP, 2014). To lower drop-out rate primary education was legitimated in 1991.

\section{LITERATURE REVIEW}

Murray (2014) explains transition as a process which requires personal growth in the social, emotional, and physical spaces of a new environment and, as with all developmental changes, it requires constant theorizing and reflection by practitioners, researchers, and policy makers. Turunen (2014) linked positive transition to positive school outcomes in academic achievement and social competence. There is a strong consensus that pedagogical discontinuities are the most pertinent with regard to the polarisation of Early Years Foundation Stage and Year 1 provision (White \& Sharp, 2007). Evidently, there is an absence of bridging between these two phases of education, meaning, children are at risk of experiencing an abrupt transition to formal schooling (Tyagi and Chawla, 2017). Transition research has pointed out an important impact on drop-out and course repetition rates if transition process is not appropriately addressed (Moreno \& Dongen, 2006). Curby et al. (2009) examined the associations between teacherchild interactions and children's achievement. Teachers' emotional support was associated with a major phonological awareness (Belsky et al. 2007). Santos (2015) found that it is good to design specific work for writing to prepare children for transition and for the child to feel safe.

Transition intervention Mauritian Development Goals: Early education has shown an effect on different aspects of a society's development. For instance, it can contribute to a country's economic and social development (Tyagi et al 2021; Painuly 2020; Tyagi...Syan, 2020) It has effect on the development of more egalitarian and healthier societies (Tyagi...Stanislavovich, 2020). In Mauritius Education is free at all levels. Mauritius designed to build a 'knowledge society' to become the Regional Knowledge Hub in Africa and the Indian Ocean. This is purposed to align Mauritius's social infrastructure with the new economic agenda (National Report on Development of Education, 2008). 'Bridging the Gap Initiative' was introduce in 2006 to facilitate the move between pre-primary and primary levels for all children (Etienne, 2007). In 2006, 32\% of pupils did not pass the primary school examination, whilst only $28 \%$ of those passing finished secondary education (MoEHR, 2009). Inequalities in school achievements also relate to socio-economic and ethnic status of families (Tyagi et al., 2020). Global Education Digest (UNESCO, 2011) noted that the provision of primary 
education worldwide increased over the previous ten years by $9 \%$, from 646 million to 702 million children. This increased rate is indicative of the importance that governments from different countries place on primary education and the current awareness of the importance of this educational level. Likewise, it reflects the commitment of worldwide educational stakeholders and policymakers to programmes created to broaden the provision of primary education, which is free and compulsory (Moreno \& Dongen, 2006). In spite of this, drop-out and school failure rates are increasing while at the same time increasing repetition rates have become a worldwide trend (UNESCO, 2006). Transition intervention have enduring upshots on children's academic achievement (Tyagi and Chawla, 2017). The high-quality childcare has positive long-term effects such as getting higher education, better employment, and higher earnings (Magnuson et al 2007; Tyagi et al 2020). Therefore, this study purposes school readiness by identifying a transition practice for the sending and receiving teachers in Mauritius.

\section{RESEARCH METHODOLOGY}

The study uses a qualitative paradigm to identify a transition practice of preschool and primary school teachers in Mauritius using qualitative methods (Zhou et al. 2008). Saturation is the most important factor that decide sample size in qualitative research (Tyagi, 2012). Study included interview method on protocol until saturation to prepare the codes, themes and writing qualitative analysis (Guetterman, 2015).

Respondents Profile: There were 18 participants in all for the study, that is, 16 teachers and 2 participants at senior level. The respondent- experience, expertise, qualifications, designation, the work place at the time of data collection is highlight in Table 1, 2 and 3.

Table 1 Receiving Teachers Demographic Profile

\begin{tabular}{|c|c|c|c|}
\hline S.No. & Respondent Detail & Qualification & $\begin{array}{l}\text { Teaching Experience } \\
\text { (Years) }\end{array}$ \\
\hline 1 & Ms Gina of James Bond Government School & Teacher's Diploma Primary & 16 \\
\hline 2 & Ms Gira of Jerome Government School & Teacher's Diploma Primary & 15 \\
\hline 3 & Ms Smita of Humpty Dumpty Primary School & $\begin{array}{l}\text { Teaching English as a } \\
\text { Foreign Language (Ireland) }\end{array}$ & 10 \\
\hline 4 & Ms Devi of Hamster Primary School & $\begin{array}{l}\text { Teaching English as a } \\
\text { Foreign Language (Ireland) }\end{array}$ & 14 \\
\hline 5 & Mr Irfan of Charlie Government School & Teacher's Diploma Primary & 20 \\
\hline 6 & Ms Riya of Jerome Government School & Teacher's Diploma Primary & 14 \\
\hline 7 & Ms Diana of Orange Private Primary School & Higher School Certificate & 15 \\
\hline 8 & Ms Jenna of Sombo Primary school & Higher School Certificate & 15 \\
\hline
\end{tabular}

The operational definition of the receiving teacher is that they are the teachers who work with new primary school entrants. They are the teachers who welcome new children to the new formal setting of primary schools.

Table 2 Sending Teachers Demographic Profile

$\left.\begin{array}{|l|l|l|l|}\hline \text { S.No. } & \text { Respondent Detail } & \text { Qualification } & \begin{array}{l}\text { Teaching } \\ \text { Experience } \\ \text { (Years) }\end{array} \\ \hline 1 & \begin{array}{l}\text { Ms Vanessa of Humpty } \\ \text { Dumpty Pre-Primary School }\end{array} & 26 \\ \hline \begin{array}{l}\text { Teachertificate of Proficiency in Early Childhood Education; } \\ \text { Teacher's Diploma in Early Childhood Education; } \\ \text { Certificate in Educational Management of Preschools }\end{array} & 10 \\ \hline 2 & \begin{array}{l}\text { Ms Noshmi of Beethoven Certificate of Proficiency in Early Childhood Education; } \\ \text { Pre-Primary School }\end{array} & \text { Teacher's Certificate in Early Childhood Education }\end{array}\right)$




\begin{tabular}{|c|c|c|c|}
\hline 3 & $\begin{array}{l}\text { Ms Shaihaar of Noah Pre- } \\
\text { Primary School }\end{array}$ & $\begin{array}{l}\text {-Diploma of Early Childhood and Care (Ireland); } \\
\text { Early Childhood Education Teacher's Certificate }\end{array}$ & 12 \\
\hline 4 & $\begin{array}{l}\text { Ms Anna from Chowchow } \\
\text { Pre-Primary School }\end{array}$ & $\begin{array}{l}\text { Certificate of Proficiency in Early Childhood Education; } \\
\text { Teacher's Certificate in Early Childhood Education; } \\
\text { Teacher's Diploma in Early Childhood Education }\end{array}$ & 13 \\
\hline 5 & 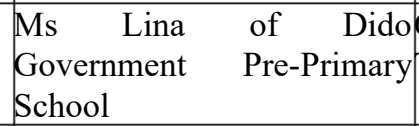 & $\begin{array}{l}\text { Certificate of Proficiency in Early Childhood Education; } \\
\text { Teacher's Certificate in Early Childhood Education }\end{array}$ & 12 \\
\hline 6 & $\begin{array}{lcc}\text { Ms Chrissy } & \text { of Aryan } \\
\text { Government } & \text { Pre-Primary } \\
\text { School } & \end{array}$ & $\begin{array}{l}\text { Certificate of Proficiency in Early Childhood Education; } \\
\text { Teacher's Certificate in Early Childhood Education }\end{array}$ & 18 \\
\hline 7 & $\begin{array}{ll}\text { Ms Holly } & \text { of Charlie } \\
\text { Government } & \text { Pre-Primary } \\
\text { School } & \end{array}$ & $\begin{array}{l}\text { Certificate of Proficiency in Early Childhood Education; } \\
\text { Teacher's Certificate in Early Childhood Education }\end{array}$ & 12 \\
\hline 8 & $\begin{array}{|lcr|}\text { Ms Enya } & \text { of } & \text { Jerome } \\
\text { Government } & \text { Pre-Primary } \\
\text { School } & & \end{array}$ & $\begin{array}{l}\text { Certificate of Proficiency in Early Childhood Education; } \\
\text { Teacher's Certificate in Early Childhood Education }\end{array}$ & 8 \\
\hline
\end{tabular}

The operational definition of the sending teacher is that they are preschool teachers working with five-year-olds who will be leaving preschool to move to primary school the next year. Sending teachers mostly hold a Teacher's Certificate in Early Childhood Education, Teacher's Diploma in Early Childhood Education.

Table 3 Senior Respondent Profile

\begin{tabular}{|l|l|l|l|}
\hline S.No. & Respondent Detail & Role & $\begin{array}{l}\text { Experience } \\
\text { (Years) }\end{array}$ \\
\hline 1 & $\begin{array}{l}\text { Mr Shyam (Retired preschool teacher and Ex-Acting } \\
\text { Director of Early Childhood Care Education Authority, } \\
\text { ECCEA) }\end{array}$ & $\begin{array}{l}\text { Education Professional } \\
\text { Tertiary Education and Scientific Research) }\end{array}$ & $>30$ \\
\hline 2 & $\begin{array}{l}\text { Ms Maya (Ministry of Education, Human Resources, } \\
\text { Tducation Policy Maker }\end{array}$ & Edo \\
\hline
\end{tabular}

The senior respondents are in policy role on developing the Transition Frame to include sending and receiving teacher practices for school readiness in Mauritius.

Reliability and Validity: For the present study, triangulation is use to ensure reliability of the research by using multiple data sources to obtain conclusions (Vishwakarma and Tyagi, 2017). This reduce bias and cross-examines the integrity of the participant's response (Tyagi 2012 b; 2011). In-depth interviews with teachers, parents of children and experts until saturation to obtain consistency, credibility and dependability of data. For the Transferability or applicability of research finding, the detail information about the school setting, the classroom, and the teachers is recorded (Hammarberg et al., 2016).

\section{DATA MANAGEMENT}

The development of descriptive and explanatory accounts on the systematic analysis of data (Ward et al., 2013). The respondents were interview for around 60 to 75 minutes. The 1500 codes are identify from the 18 interview transcripts and 160 initial categories are derive from the identified codes. Finally, 33 refined categories generated 16 initial themes to give 5 final themes leading to the core concept, 'Transition Diary'. The transition diary components are encapsulate in table 4 . The table 4 highlights the observation of the sending teachers for receiving teachers for transition management. 
Table 4 Transition Management

\begin{tabular}{|l|l|l|}
\hline \multicolumn{3}{|c|}{ (Transition Diary Components) } \\
\hline S.No & Observation Item & Remarks \\
\hline $\mathbf{1}$ & Morning routine & \\
\hline $\mathbf{2}$ & Warm-up activities & \\
\hline $\mathbf{3}$ & Subjects and content & \\
\hline $\mathbf{4}$ & Teaching approaches and strategies & \\
\hline $\mathbf{5}$ & Expectations of receiving teachers & \\
\hline $\mathbf{6}$ & What children do independently & \\
\hline $\mathbf{7}$ & Socialisation of children & \\
\hline $\mathbf{8}$ & Interaction between teacher and children & \\
\hline $\mathbf{9}$ & Class routine & \\
\hline $\mathbf{1 0}$ & End of the day routine & \\
\hline
\end{tabular}

\section{ANALYSIS AND DISCUSSION}

The analysis on the observation item wise is as follows:

Item 1- Morning routine: In preschools, the teacher welcome children at the door and greet both parents and their children. In primary schools, parents drop children at the door irrespective if the class teacher is there or not. In preschools, when children reach their classrooms, they start doing any activity of their choice, whereas in primary schools, children have time to socialise with their peers, walk around the classroom. However, there are no toys available as in preschools. When the ring bells, children queue up and follow the class teacher to the yard where the headmaster does the assembly. In preschools, there is only a class prayer done in class. Due to these differences, sending teachers need to know about the morning routine in primary schools to prepare young learners to be ready for this change.

Reporting morning routine will enable sending teachers to prepare children to follow rules and teach them to obey and abide by those rules.

Item 2- Warm-up activities: To attract the attention of students towards each other. Sending teachers opine to include warm-up activities as a pedagogical tool in the last trimester to encourage and prepare children for smooth transition and school readiness. Warm-Up activity work as engagement activity and rouse pupil curiosity (Dornyei, 2001). Warm-up helps children feel relaxed and sets the mood for learning (Rushidi, 2013, p.130).

Item 3-Subjects and contents: In primary schools, children learn through subjects. They have a book specifically for each subject. Sending and Receiving both teachers emphasise that discussion between the two teachers will help sending teacher know how to prepare pupil for the receiving teacher for smooth transition. Teachers at both levels need to have content knowledge and pedagogical content knowledge of the subject (Walan \& Chang-Rundgren, 2014, p. 63).

Item 4- Teaching approaches and strategies: Teaching in primary school is formal and subject-based, unlike in preschools where it is play-based. While observing the teaching approaches and strategies that receiving teachers use in the primary school classrooms, sending teachers may try to adopt some of the strategies in the last trimester of the school year so children get acquainted to them. Teaching and learning in preschool setting gets transformed from play-based pedagogy to subject-based formal teaching and learning (Karila and Rantavuori, 2014).

Item 5- Expectations of receiving teachers: Receiving teachers complained that children lack knowledge and skills to be in primary schools. It implies that the preparedness of the new learners is not meeting the expectations of the primary school teachers. The expectation of receiving teachers are on children's healthy development related to physical, social, and 
cognitive abilities. Observing the practice of receiving teachers, noting down their expectations will enable sending teachers to look into their own practices in preparing children for the transition from preschools to primary schools. The expectation of primary school teacher lie in the demands of school readiness (Peckham, 2017).

Item 6- What children do independently: Sending teacher participants are confident about preparing children to be autonomous. However, children face challenges in the different school settings; especially in decision-making and to do things on their own. The receiving teachers emphasise upon fostering independent skills in children. Research shows autonomy-building competence must be embed in practices of teachers (Peckham, 2017).

Item 7-Socialisation of children: Findings shows the socialisation process that children go through at the time they enter primary schools may enable preschool teachers to foster socioemotional development of children that will allow them to cope in the new school. The findings suggest that receiving teachers give opportunity to each new entrant to communicate and interact. However, they do not have enough time to provide support to those children who are shy and timid. Consequently, the quality of the interaction influences children's adaptation to school and the motivation to learn. Teachers operate as social agents who can influence the intellectual and socio-emotional experiences of students by creating a classroom setting that stimulates both student motivation and learning (Koca, 2016).

Item 8- Interaction between teacher and children: The sending and receiving teacher emphasise on the social interaction and the emotional need of pupil where the sending teacher highlight inclusion of self-led activity as pedagogical tool to support the receiving teacher with proper note of performance record of the child. The receiving teacher highpoint that many children drop out due to their inability to take up self-led activity and classroom exercise.

Item 9- Class routine and Item 10- End of the day routine: The routine of the child differs in both the setting. 'Routine' is "well-defined repetitive patterns characteristic of a given discourse" (Sfard, 2008, p.128). Sending teachers in the transition diary expect the routine of primary school classroom to add so that they may develop the ward with an understanding to prepare children to comply with authority, rules, timekeeping, and routines. Receiving teachers anticipate a note from the sending teacher on how the sending teacher start and end a lesson to help the transition from one subject to another, and breaks and recess routines. They also want to learn about what receiving teachers do to close the day and send children back home to smoothen the transition days of the child. The daily routine of a child change drastically as from what they have been use to before starting formal schooling (Peckham, 2017).

\section{IMPLICATIONS}

Recommendations on National Curriculum Framework, 2015: National Curriculum Framework Grades $1-6$ proposed a number of recommendations to improve learning outcomes and adapt to rapid changes and emerging challenges (NCF Primary 2015). There is a need for Transition Management through observation diary (Rajiah and Aliraja, 2016).

Sustainable Development Goals on early year's education: The objectives are associated with the idea of provision of successful early education worldwide. Preschool-considered as level 0 in the International Standard Classification of Education (ISCED, 1997) - and primary education-level 1-are now seen as mandatory in different countries around the world importantly focusing on enrolment rates and the provision and quality of education services (Global Monitoring Report, EFA, UNESCO, 2007).

Role of institutional quality in promoting economic growth: The quality of institutions should be made robust and sustainable (Tyagi and Vasiljevien, 2013). Good governance could play a major role in attracting FDIs, maintain economic, social and political stability - basic ingredients for positive and sustainable economic progress (Tyagi, 2011; Gupta et al 2021). 
Low Skill Enhancement through Certificate of Primary Education: Address the deficit in learning outcomes, accumulate at the early years of primary schooling (Morabito et al. 2017)..

Establishment of Zones d'Education Prioritaires (ZEP): ZEP school is recommend by this study to combat social inequalities by providing equal opportunities to all primary school children. ZEP is seen as holistic educational approach, school-community partnership, active involvement of parent in the educational process, and a fund-raising model for school improvement projects.

\section{LIMITATIONS}

- There is a dearth of qualitative study on policy framework for transition practices of preschool and primary school teachers in Mauritius. Therefore, reference theories and adopted applications are limited (Ali and Tyagi, 2020).

- Epistemological stance of the interviewer influence (Tyagi, 2010) the coding process that might bring up biases. The term bias reflects the ability of twisting the data intentionally or unintentionally.

\section{CONCLUSIONS}

The Transition management of the sending and receiving teacher is important for the smooth transition of the children to prepare them adequately for the transition to formal school. The transition diary with observation form may support teachers from both settings to observe the practices of each other. The transition diary can be centrally online and in access to all the stakeholders for the smooth transition and child development (Tyagi...Mohammed, 2020) The dropout of the children has skill implications that in turn affect the socio-emotional and economic setup of the country. Further, the study concludes the transition management of sending and receiving teacher has long-term effect on the equality and education targets of Sustainable Development Goals.

\section{REFERENCES}

[1] Ali SS, and Tyagi Ruchi (2020) The role of Energy Conservation Building Code 2017 in Indian Energy Policy. International Journal of Recent Technology and Engineering (IJRTE) 9(1):1799-1806 Blue Eyes Intelligence Engineering \& Sciences Publication. DoI: 10.35940/ijrte.A2212.059120. Available at https://www.ijrte.org/wpcontent/uploads/papers/v9i1/A2212059120.pdf

[2] Belsky, J., Vandell, D.L., Burchinal, M., Clarke-Stewart, K.A., McCartney, K., \& Owen, M.T. (2007) Are there long-term effects of early child care? Child Development, 78(2), 681701.

[3] Curby, T. W., Rimm-Kaufman, S. E., \& Ponitz, C. C. (2009). Teacher-child interactions and children's achievement trajectories across kindergarten and first grade. Journal of Educational Psychology, 101(4), 912-925. https://doi.org/10.1037/a0016647.

[4] Dornyei, Z. (2001). Motivational strategies in the English classroom. Cambridge: Cambridge University Press.

[5] Etienne P. (2007). "Bridging the gap”" still needs to convince teachers.'. L'Express.

[6] Global Education Digest. (2011). Comparing education statistics across the world focus on secondary education. 
[7] Guetterman, T. C. (2015). Descriptions of sampling practices within five approaches to qualitative research in education and the health sciences. Forum Qualitative Sozial Forschung, 16, 1-23.

[8] Gupta S., Tyagi R., Sharma A., Singh H. (2021). Human Wealthsurance: Analytical Study on Financial Planning of Community Investors during COVID-19. International Journal of Management (IJM).12 (1). 1453-1473. DOI: 10.34218/IJM.12.1.2021.128

Available at:

http://iaeme.com/MasterAdmin/Journal_uploads/IJM/VOLUME_12_ISSUE_1/IJM_12_0 1_128.pdf

[9] Hammarberg K, M. Kirkman, S. de Lacey, Qualitative research methods: when to use them and how to judge them, Human Reproduction, Volume 31, Issue 3, March 2016, Pages 498501, https://doi.org/10.1093/humrep/dev334

[10] Hollup, O. (n.d.). HiT Publication no 8/2004 Educational policies, reforms and the role of teachers unions in Mauritius. Retrieved from http://www.hit.no/

[11] Karila, K., \& Rantavuori, L. (2014). Discourses at the boundary spaces: developing a fluent transition from preschool to school. Early Years, 34(4), 377-391. https://doi.org/10.1080/09575146.2014.967663

[12] Koca, F. (2016). Motivation to Learn and Teacher-Student Relationship. Journal of International Education and Leadership, 6(2), 1-20.

[13] Magnuson, K. A., Ruhm, C., Waldfogel, J. (2007). The persistence of preschool effects: Do subsequent classroom experiences matter? Early Childhood Research Quarterly, 22(1), 18 38.

[14] Meade E J (2013). The Economic and Social Structure of Mauritius. First copyright year 1961. Routledge.

[15] Moreno, T. \& Dongen, J. (2006). Transitions in the early years: A learning opportunity. The Netherlands: Bernard van Leer Foundation.

[16] Ministry of Education, Culture \& Human Resources, EHRSP (2009). Education \& Human Resources Strategy Plan 2008-2020. Phoenix: IVTB House; 2009.

Available online at http://ministry-education.govmu.org/English/Documents/Publications/EHRSP\%2020082020.pdf

[17] Morabito, C., Carosin, E., \& Vandenbroeck, M. (2017). What parents say about children's inequality of opportunities: a study in Mauritius. Early Years, 37(4), 423-437. https://doi.org/10.1080/09575146.2016.1211994

[18] Murray E. (2014) Multiple Influences on Children's Transition to School. In: Perry B., Dockett S., Petriwskyj A. (Eds) Transitions to School - International Research, Policy and Practice. International perspectives on early childhood education and development, vol 9. Springer, Dordrecht. https://doi.org/10.1007/978-94-007-7350-9_4.

[19] National Curriculum Framework Nine-Year Continuous Basic Education (n.d.).

[20] National Research Council. (2001). Adding it up: Helping children learn mathematics. Washington, DC: The National Academies Press. https://doi.org/10.17226/9822. 
[21] Policy brief. www.sacmeq.org. ((n.d.-a)).

[22] Painuly P.K., Tyagi R., Vishwakarma S., Khare S.K., Haghighi M. (2020) Energy Supply Using Nexus Approach for Attaining Sustainable Development Goal 7. In: Leal Filho W., Azul A.M., Brandli L., Lange Salvia A., Wall T. (eds) Affordable and Clean Energy. Encyclopedia of the UN Sustainable Development Goals. Springer, Cham. https://doi.org/10.1007/978-3-319-71057-0_84-1 Online ISBN 978-3-319-71057-0

[23] Peckham, K. (2017) Developing School Readiness: Creating Lifelong Learners. London: Sage.Peckham, K. (2017) Supporting effective readiness in all school children. Journal of Health Visiting. 5 (7), pp. 342-345.

[24] Rajiah, Saraswatee and Aliraja, Salim, Early Identification and Intervention in Early Years: Preschool Teachers in Mauritius (June 30, 2016). International Journal of Educational Science and Research (IJESR), Vol. 6, Issue 3, June 2016, Available at SSRN: https://ssrn.com/abstract=2838189

[25] Rushidi, J. (2013). The Benefits and Downsides of Creative Methods of Teaching in an EFL Classroom: A Case Study Conducted at South East European University, TetovoMacedonia. Journal of Education and Practice.

[26] Sfard, A. (2008). Thinking as communicating: Human development, the growth of discourses, and mathematizing. Cambridge: Cambridge University Press.

[27] Santos, A. I. (2015). Between Preschool and Primary Education-Reading and Writing from the Perspective of Preschool and Primary Teachers. International Education Studies, 8(11), 211. https://doi.org/10.5539/ies.v8n11p211

[28] Subramanian, A., and D. Roy. 2001. "Who Can Explain the Mauritian Miracle: Meade, Romer, Sachs, or Rodrik?” IMF working paper, WP/01/116, Washington, DC.

[29] Turunen T. (2014) Experienced and Recalled Transition: Starting School as Part of Life History. In: Perry B., Dockett S., Petriwskyj A. (Eds) Transitions to School - International Research, Policy and Practice. International perspectives on early childhood education and development, vol. 9. Springer, Dordrecht. https://doi.org/1007/978-94-007-7350-9_11

[30] Tyagi R., Vishwakarma S., Rishi M., Rajiah S. (2021) Reducing Inequalities Through Education and Skill Development Courses. In: Leal Filho W., Azul A.M., Brandli L., Lange Salvia A., Özuyar P.G., Wall T. (eds) Reduced Inequalities. Encyclopedia of the UN Sustainable Development Goals. Springer, Cham. https://doi.org/10.1007/978-3-31971060-0_102-1

[31] Available at: https://ink.springer.com/referenceworkentry/10.1007/978-3-319-710600_102-1 Online ISBN 978-3-319-71060-0

[32] Tyagi Ruchi., Vishwakarma S., Yadav S.S., Stanislavovich T.A. (2020). Community SelfHelp Projects. In: Leal Filho W., Azul A., Brandli L., Lange Salvia A., Özuyar P., Wall T. (eds) No Poverty. Encyclopedia of the UN Sustainable Development Goals. Springer, Cham. DOI https://doi.org/10.1007/978-3-319-69625-6.

[33] Tyagi Ruchi., Vishwakarma S., Alexandrovich Z.S., Mohammed S. (2020). ICT Skills for Sustainable Development Goal 4. In: Leal Filho W., Azul A.M., Brandli L., Özuyar P.G., Wall T. (eds) Quality Education. Encyclopedia of the UN Sustainable Development Goals. Springer, Cham. DOI https://doi.org/10.1007/978-3-319-95870-5_39 
[34] Tyagi R., Vishwakarma S., Singh K.K., Syan C. (2020) Low-Cost Energy Conservation Measures and Behavioral Change for Sustainable Energy Goal. In: Leal Filho W., Azul A.M., Brandli L., Lange Salvia A., Wall T. (eds) Affordable and Clean Energy. Encyclopedia of the UN Sustainable Development Goals. Springer, Cham. https://doi.org/10.1007/978-3-319-71057-0_155-1

[35] Tyagi, Ruchi and Chawla G. (2017) Education through Information and Communication Technology: Student Perspective on the Blended Learning. International Journal of Social Science and Humanity. 7 (4): 212-216. DoI: 10.18178/ijssh.2017.7.4.822. Available at http://www.ijssh.org/vol7/822-NH3005.pdf

[36] Tyagi, Ruchi K and Vasiljevien, Nijole (2013) The case of CSR and irresponsible management practices. Competitiveness Review. 23(4/5):372-383. https://doi.org/10.1108/CR-03-2013-0031. Available online at https://www.emerald.com/insight/content/doi/10.1108/CR-03-2013-0031/full/html .

[37] Tyagi R. (2012) Sustaining by working at the bottom of the pyramid: a case of Indian rugs manufacturing company. Societal Studies.4 (2): 427-442. Mykolas Romeris University. Available online at https://www3.mruni.eu/ojs/societal-studies/article/view/730

[38] (b) Tyagi R. (2012) Meerut Embroidery Cluster: A Case Study. South Asian Journal of Business and Management Cases. 1 (2): 185-202. SAGE Publications Sage India: New Delhi, India. doi:10.1177/2277977912459445

[39] Tyagi, R. K. (2011) Indian Perspective on Ethical Implementation in Academic and Business Community: A Discourse through Case Study on Education and Industry. Paper Presented in absentia at International Conference. December 09-10, 2010 UNESCO Chair, Russian State Pedagogical University. Alexander Herzen, St. Petersburg. [Publish in Humanities, Humanitarian Knowledge, Humanities, Humanitarian Knowledge, Humanitarian Education Problems and Perspectives Vol II, 117-126, Asterion Publication, Russia. ISBN 978-5-9856-809-6].

[40] Tyagi RK (2010) Dynamics of corporates and stakeholders perspective of corporate social responsibility: a case of sports goods industry Meerut. American Journal of Economics and Business Administration. 2(2) 169. Accessed at

http://citeseerx.ist.psu.edu/viewdoc/download?doi=10.1.1.663.3297\&rep=rep1\&type=pdf

[41] UNESCO, United Nations Educational, Scientific and Cultural Organization (2006) UNESCO Guidelines on Intercultural Intercultu ntercultu u Education.

[42] UNESCO, United Nations Educational, Scientific and Cultural Organisation (2007) Global Monitoring Report, EFA, UNESCO, 2007 available at https://unesdoc.unesco.org/ark:/48223/pf0000108527

[43] UNESCO, United Nations Educational, Scientific and Cultural Organisation (2011) United nations educational, scientific and cultural organization. (1950). International Organization, 4(2), 326-327. https://doi.org/10.1017/S0020818300029234

[44] Vishwakarma, S. and Tyagi, R. (2017), "Post-reforms training needs of frontline managers in Indian power distribution companies: A top managers' perspective", International Journal of Energy Sector Management. 11(3): 416-425.https://doi.org/10.1108/IJESM-022016-0001. Accessed at https://www.emerald.com/insight/content/doi/10.1108/IJESM-022016-0001/full/html 
[45] Ward et al., 2013 Impact of COVID-19 on the Insurance Sector. (2020). Retrieved from https://www.linkedin.com/pulse/insurance-covid19-spotlight-nigel-walsh

[46] Walan S., \& Chang Rundgren, S. N. (2014) Investigating preschool and primary school teachers' self-efficacy and needs in teaching science: a pilot study. Centre for Educational Policy Studies Journal, 4(1), 51-67 - URN: urn:nbn:de:0111-opus-88792.

[47] World Bank Report, WBR (2006) Country Partnership Strategy for Republic of Mauritius, International Bank For Reconstruction and Development (IBRD)/World Bank: Washington, D.C.

Available on-line at http://wwwwds.worldbank.org/external/default/WDSContentServer/WDSP/IB/2006/11/27 /000020953_2 0061127115847/Rendered/PDF/37703.pdf

[48] White, G. \& Sharp, C. (2007). 'It is different ... because you are getting older and growing up.' How children make sense of the transition to Year 1. European Early Childhood Education Research Journal, 15(1), 87-102.

[49] Zafar (2011). Mauritius: An Economic Success Story. World Bank Group

[50] Zhou, Y., Jindal-Snape, D., Topping, K. and Todman, J. (2008) 'Theoretical models of culture shock and adaptation in international students in higher education', Studies in Higher Education, 33(1), pp. 63-75. doi: 10.1080/03075070701794833 